\title{
Optimization and Analysis of Cost For Bridge Super-Structure of 25m Span Above Rail Track
}

\author{
Natraj Singh ${ }^{1}$, Dr. N.P. Devgan ${ }^{2}$, Dr. A.M. Kalra ${ }^{3}$, and Surinder Pal ${ }^{4}$
}

\begin{abstract}
In this present study an attempt is made to optimize the cost of the superstructure of bridge of $25 \mathrm{~m}$ span. The Four types of the superstructures used for the study purpose are; reinforced concrete T-beam, reinforced concrete I- beam, prestressed concrete I-beam and steel composite I-beam. The analysis and design is done based on the loading standards of the Indian Road Congress (IRC). The repercussions of launching above the railway line and the indirect effect of cost in terms of block cost \& speed restriction cost is studied in details. Further, the effect of use of sacrificial shuttering with combination of conventional shuttering for the deck slab is studied in details. On the basis of material cost as well as placement cost above railway line, RCC T-beam is most economical among the four options. However, PSC I-section proves to be most economical when launching of girders by hydraulic crane is considered without considering the indirect cost. The use of sacrificial shuttering in deck slabs increases the cost nominally when material cost is considered, but when its effect is analyzed with the cost component of the block cost and speed restriction cost it proves to be an economical and judicious selection. Lifecycle cost is minimum for Composite steel girder with RCC deck slab for both types of shuttering where launching is involved.
\end{abstract}

Keywords - Reinforced concrete T-beam, reinforced concrete I- beam, prestressed concrete I-beam, steel composite I-beam, DFC (Dedicated Freight Corridor), IRC (Indian Road Congress)

\section{INTRODUCTION}

India's vision for sustaining high economic growth is based on investment in infrastructure sector. In twelfth five year plan, the target of investment in infrastructure is US $\$ 1$ trillion. The important portion of this capital is to be spent on ageing and congested transport infrastructure. Government of India has decided to build dedicated freight corridor as a long term plan to boost the Indian economy. Initially two corridors are under construction comprising total length of approximately $3300 \mathrm{~km}$. As the DFC(dedicated freight corridor) track will run parallel to the existing network of Indian railway, this will increase the traffic congestion at level crossing gates. Generally on Indian railway, there is a level crossing at approximately $1.5 \mathrm{~km}$ distance. The parallel addition of new track will increase the duration period of closure of level crossing gates and more inconvenience will be caused to the public. Further, safety of public and Railways will remain under threat at these Level crossing gates. Keeping this problem in view Indian railway has decided to eliminate all these level crossings on these two corridors by constructing road over bridges or road under bridges. For a growing country like India, the expenditure on elimination on these level crossings is a big challenge. The designers generally

1,4 Dedicated Freight Corridor Corporation of India Ltd. Old Railway Colony, Ambala Cantt, India First.natraj_singh2000@yahoo.co.in; Fourth.spal@dfcc.co.in

2,3PEC University of Technology, Sector-12, Chandigarh, India Second.npdevgan@gmail.com; Third.kalra_aditya@yahoo.com. consider the direct cost to be involved for bridge construction and do not consider the indirect cost like railway traffic block and speed restriction cost.

In this paper efforts have been made to optimize the resources directly and indirectly involved in the super structure of the bridges. Four different types of super structures are considered for this purpose namely: reinforced concrete T-beam, reinforced concrete I-beam, prestressed concrete I-beam and steel composite I-beam. For the analysis and design purposes, the loading standard of the Indian Road Congress (IRC) have been adopted.

\section{Design PhILOSOPHY}

The bridge superstructure having span of $26.96 \mathrm{~m}$ with effective span of $25 \mathrm{~m}$ is analyzed by the grillage analysis for main girders along the longitudinal direction and slabs in the transverse direction. For a clear carriageway of $7.5 \mathrm{~m}$, with footpath on both sides, four longitudinal girders are considered to support the deck slab. The spacing between the longitudinal girders is assumed as $2.65 \mathrm{~m}$. The width of the superstructure is taken as $12 \mathrm{~m}$ for the study purpose based on the standard section of IRC. The details of the sectional properties are given in the Table I, and are based on the design criteria given by IRC.

TABLE I

SECTIONAL PROPERTIES OF GIRDERS CONSIDERED FOR COMPARISON

\begin{tabular}{|c|l|c|c|c|c|c|}
\hline No & \multicolumn{1}{|c|}{ Description } & Unit & $\begin{array}{c}\text { RCC-I } \\
\text { Section }\end{array}$ & $\begin{array}{c}\text { RCC-T } \\
\text { beam }\end{array}$ & $\begin{array}{c}\text { PSC-I } \\
\text { Section }\end{array}$ & $\begin{array}{c}\text { Steel } \\
\text { Composite }\end{array}$ \\
\hline 1 & Depth of deck slab & $\mathrm{m}$ & 0.25 & 0.25 & 0.25 & 0.25 \\
\hline 2 & $\begin{array}{l}\text { Web depth(excluding } \\
\text { deck slab) }\end{array}$ & $\mathrm{m}$ & 2 & 2.3 & 1.85 & 1.67 \\
\hline 3 & $\begin{array}{l}\text { Top Flange width (at } \\
\text { mid span) }\end{array}$ & $\mathrm{m}$ & 0.73 & 0.93 & 1 & 0.4 \\
\hline 4 & $\begin{array}{l}\text { Web width (at mid } \\
\text { span) }\end{array}$ & $\mathrm{m}$ & 0.38 & 0.33 & 0.3 & 0.012 \\
\hline 5 & Web width (at Support) & $\mathrm{m}$ & 0.73 & 0.63 & 0.8 & 0.012 \\
\hline 6 & $\begin{array}{l}\text { Bottom Flange width (at } \\
\text { mid span) }\end{array}$ & $\mathrm{m}$ & 0.73 & 0.63 & 0.8 & 0.6 \\
\hline
\end{tabular}

The concrete of M35 grade is considered for the RCC work and M40 grade for the PSC works. For the purpose of reinforcement, TMT Fe500 is considered for all types of RCC \& PSC works.

\section{Methodology fOR the Cost Optimization :}

Broadly the cost associated with any construction work can be divided in two components, one component is direct cost and another is indirect cost. As the name suggests, the direct cost is cost directly quantifiable based on the design specification and the other associated construction methodologies. The indirect cost is the cost component which does not figure directly in the cost analyses of the structure and cost impact of the indirect component is derivative cost which is influenced by many factors and among which location is the major influencing factor. In the present study the emphasis is made on the quantification of both direct as 
well as indirect cost associated with the construction of the bridges over the Railway lines. The schematic diagram showing various activities involved in the construction of super structure of bridge above railway track is shown in the shape of flow chart, Fig: 1.

\subsection{Direct Cost:}

In this present study the construction of the bridge above the Railway line is studied in the detail. Accordingly the direct cost of the structure involves the following components:

- Basic material cost

- Cost associated with the fabrication/construction of the structural components

- Transportation cost

- Placement/launching cost.

\subsection{Indirect Cost:}

The indirect cost associated with any structure cannot be generalized and is dependent on many variables. These variables are related with location of bridge, frequency of trains in a section, space constraints, type of cranes and other resources etc. In the present case the indirect cost associated with the construction of bridges across the Railway line is considered. The work of construction of bridges across the railway line affects the normal railway traffic of the section. Accordingly, the present study is dedicated to quantify the indirect cost components associated with the construction of bridges across the railway line. This cost consists of two parts,

- The cost associated with the Railway Traffic Block,

- and the cost associated with the Speed Restriction.

The effect of periodic maintenance cost is not considered for the present study.

\subsection{Estimation of Direct cost:}

\subsubsection{Basic Material Cost}

The basic material cost is calculated by multiplying the prevalent rates with the quantities of the superstructure for $25 \mathrm{~m}$ span. The quantities have been calculated after detailed analysis and design for $25 \mathrm{~m}$ span for all superstructure types. The quantities have been bifurcated into five main heads and details are given in Table II.

TABLE II

QuANTITIES OF MATERIALS REQUIRED For VARIOUS TYPE OF SUPER-STRUCTURES

\begin{tabular}{|c|l|c|c|c|c|c|c|}
\hline \multirow{2}{*}{ No } & $\begin{array}{c}\text { Type of } \\
\text { Superstructure }\end{array}$ & $\begin{array}{c}\text { Qty of Material per Span (Including Deck Slab) } \\
\text { Concrete } \\
\text { (Cum) }\end{array}$ & $\begin{array}{c}\text { Reinforcemen } \\
\mathbf{t}(\mathrm{MT})\end{array}$ & $\begin{array}{c}\text { Shuttering } \\
\text { (Sqm) }\end{array}$ & $\begin{array}{c}\text { Pre- } \\
\text { Stressing } \\
\text { Cable } \\
\text { (Kg.) }\end{array}$ & $\begin{array}{c}\text { Structural } \\
\text { Steel (MT) }\end{array}$ & $\begin{array}{c}\text { Construction/ } \\
\text { Fabrication } \\
\text { Cost (material } \\
\text { cost) in INR }\end{array}$ \\
\hline 1 & RCC T-beam & 203 & 38 & 960 & 0 & 0 & 4313368 \\
\hline 2 & RCC I-beam & 210 & 43 & 856 & 0 & 0 & 4728597 \\
\hline 3 & PSC I-Section & 202 & 29 & 791 & 4700 & 0 & 4405566 \\
\hline 4 & $\begin{array}{l}\text { Composite Steel } \\
\text { girder and RCC } \\
\text { deck slab }\end{array}$ & 76 & 11.6 & 297 & 0 & 55 & 5497071 \\
\hline
\end{tabular}

It is clear from Table II that on the basis of construction/fabrication cost RCC T-beam is most economical among all other type of superstructures considered for study. The difference in cost between RCC T-beam and PSC I-section is also very small.

\subsubsection{Effect of Sacrificial Shuttering}

The sacrificial shuttering is considered in combination with conventional shuttering. The sacrificial shuttering is the integral part of the concrete structure and left embedded in the structure after concreting. For the present study, the use of sacrificial shuttering is studied for the Concreting of the Deck Slab of the bridges over railway line.

From Table III, It is clear that the combination of the sacrificial shuttering with conventional shuttering, enhances the Construction/ Fabrication Cost (material cost) by 3\% in case of RCC-I section and PSC-I section and by $1 \%$ in case of Composite Steel girder and RCC deck slab. The use of sacrificial shuttering is not considered for the RCC T-beam as it is constructed Caste-in-situ and the use of sacrificial shuttering in such cases may not be useful.

TABLE III

EFFECT OF SACRIFICIAL SHUTTERING ON CONSTRUCTION/ FABRICATION COST (MATERIAL COST)

\begin{tabular}{|c|c|c|c|c|c|c|}
\hline No. & $\begin{array}{c}\text { Construction/ } \\
\text { Fabrication } \\
\text { Cost } \\
\text { Structure } \\
\text { Tyaterial } \\
\text { cost) with } \\
\text { Conventional } \\
\text { Shuttering (in } \\
\text { INR) }\end{array}$ & $\begin{array}{c}\text { Construction/ } \\
\text { Fabrication } \\
\text { Cost with } \\
\text { Combination of } \\
\text { Conventional + } \\
\text { Sacrificial } \\
\text { Shuttering (in } \\
\text { INR) }\end{array}$ & $\begin{array}{c}\text { Total Cost } \\
\text { including } \\
\text { Launching } \\
\text { Above } \\
\text { Railway Line } \\
\text { with } \\
\text { Conventional } \\
\text { Shuttering }\end{array}$ & $\begin{array}{c}\text { Total Cost } \\
\text { including } \\
\text { Launching Above } \\
\text { Railway Line Cost } \\
\text { with Combination } \\
\text { of Conventional + } \\
\text { Sacrificial } \\
\text { Shuttering }\end{array}$ & $\begin{array}{c}\text { \% Change in } \\
\text { Construction/ } \\
\text { Fabrication } \\
\text { Cost } \\
\text { (material } \\
\text { cost) }\end{array}$ \\
\hline 1 & $\begin{array}{l}\text { RCC- T } \\
\text { Bcam }\end{array}$ & 4313368 & 4313368 & 4313368 & 4313368 & $0 \%$ \\
\hline 2 & $\begin{array}{l}\text { RCC-I } \\
\text { section }\end{array}$ & 4728597 & 4877442 & 5728597.2 & 5877442 & $3 \%$ \\
\hline 3 & $\begin{array}{l}\text { PSC -I } \\
\text { Section }\end{array}$ & 4405566 & 4537571 & 5405566.3 & 5537571 & $3 \%$ \\
\hline 4 & $\begin{array}{l}\text { Composite } \\
\text { Steel } \\
\text { girder and } \\
\text { RCC deck } \\
\text { slab }\end{array}$ & 5497071 & 5576667 & 5697070.8 & 5776667 & $\mathbf{1} \%$ \\
\hline
\end{tabular}

The use of sacrificial shuttering mainly affects the Speed restriction duration. The Table IV shows the reduced speed restriction time with the use of sacrificial shuttering. This reduction in speed restriction changes the total cost associated with the speed restriction.

\subsubsection{Transportation Cost}

In the present study, the casting/fabrication yard is considered near the bridge construction site. So no substantial cost is involved in transportation of the girders. Further the transportation cost is vital where there is repetition of spans and casting/fabrication yard is away from the bridge construction site. Hence, the component of transportation cost is not considered for present study.

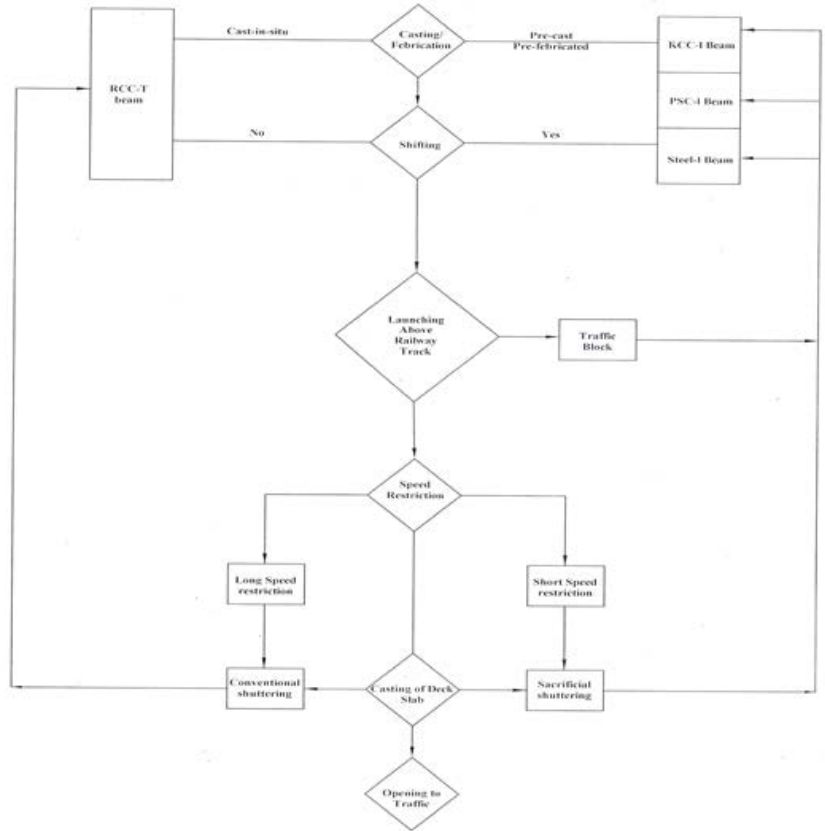

Fig. 1: Schematic diagram showing various activities involved in the construction of super structure of bridge above railway track

\subsubsection{Placement/Launching Cost}


The pre-fabricated girders/bridge component requires launching/placement at the designated locations by means of hydraulic cranes. The cost component for launching/placement plays a significant role in overall economy of superstructure. In the present study, the case of launching above the railway line is studied in detail. The presence of railway line greatly affects the overall cost of the bridge and imposes restrictions for free movement of hydraulic crane. During the launching/placement operation the train movement is stopped; in Indian railway terminology this is termed as Traffic Block. This traffic block puts huge financial burden on the already cash strapped Indian Railways and this cost is further compounded with increase in the number of trains in the particular section. The duration of the traffic block depends upon the working space for cranes, type of cranes, capacity of cranes, weight of the component, etc. It is clear from the Table III, the composite cost(material cost+ launching above railway line without block cost and speed restriction cost) is minimum for PSC I- section for $25 \mathrm{~m}$ spans. The RCC T-beam is constructed caste-in-situ at site and does not require any launching.

\subsection{Estimation of Indirect cost:}

\subsubsection{Cost Associated with Block cost and Speed restriction cost}

To ensure the safety of public and trains, traffic block is availed during the launching operation of girders. During the traffic block, the movement of all trains is suspended in that particular block section. As there is a detention and idling of resources of railways, there is a loss of revenue generation and it causes unproductiveness of railway resource. This loss increases with increase in number of trains in the section.

TABLE IV

DETAILS OF Block DURATION AND SPEEd RESTRICTION Time DURATION FOR CONVENTIONAL AND COMBINATION OF CONVENTIONAL+ SACRIFICIAL SHUTTERING

\begin{tabular}{|c|l|c|l|c|c|}
\hline \multirow{2}{*}{ No } & $\begin{array}{c}\text { Super-structure } \\
\text { Type }\end{array}$ & \multicolumn{2}{|c|}{$\begin{array}{c}\text { with Conventional } \\
\text { Shuttering }\end{array}$} & \multicolumn{2}{c|}{$\begin{array}{c}\text { with combination of } \\
\text { Conventional+ Sacrificial } \\
\text { Shuttering }\end{array}$} \\
\cline { 3 - 6 } & $\begin{array}{l}\text { block } \\
\text { duration } \\
\text { in Hours }\end{array}$ & $\begin{array}{l}\text { Speed } \\
\text { restriction } \\
\text { Duration in } \\
\text { Days }\end{array}$ & $\begin{array}{l}\text { lock } \\
\text { block } \\
\text { duration in } \\
\text { Hours }\end{array}$ & $\begin{array}{l}\text { Speed } \\
\text { restriction } \\
\text { Duration } \\
\text { in Days }\end{array}$ \\
\hline 1 & RCC- T Beam & 2.5 & 15 & 2.5 & 15 \\
\hline 2 & RCC- I section & 3.5 & 15 & 3.5 & 3 \\
\hline 3 & PSC -I Section & 3.5 & 15 & 3.5 & 3 \\
\hline 4 & $\begin{array}{l}\text { Composite Steel } \\
\text { girder and RCC } \\
\text { deck slab }\end{array}$ & 2.5 & 15 & 2.5 & 3 \\
\hline
\end{tabular}

TABLE V

TOTAL COMPOSITE COST INCLUDING FABRICATION/CONSTRUCTION Cost, LAunChing ABove RaILWAy Line, Traffic Block AND SPEED RESTRICTION COST (IN LAKHS OF INR) FOR CONVENTIONAL AND COMBINATION OF CONVENTIONAL+ SACRIFICIAL SHUTTERING

\begin{tabular}{|c|c|c|c|c|c|c|c|c|c|}
\hline \multirow[b]{3}{*}{ No } & \multirow[b]{3}{*}{$\begin{array}{l}\text { Supper- } \\
\text { structure } \\
\text { Type }\end{array}$} & \multicolumn{4}{|c|}{20 Trains per day } & \multicolumn{4}{|c|}{50 Trains per day } \\
\hline & & \multicolumn{2}{|c|}{ Conventional Shuttering } & \multicolumn{2}{|c|}{$\begin{array}{c}\text { Combination of } \\
\text { Conventional + Sacrificial } \\
\text { Shuttering }\end{array}$} & \multicolumn{2}{|c|}{$\begin{array}{c}\text { Conventional } \\
\text { Shuuttering }\end{array}$} & \multicolumn{2}{|c|}{$\begin{array}{l}\text { Combination of } \\
\text { Conventional + Sacrificial } \\
\text { Shuattering }\end{array}$} \\
\hline & & $\begin{array}{c}\text { Block } \\
\text { Cost+ } \\
\text { Speed } \\
\text { restriction } \\
\text { cost }\end{array}$ & $\begin{array}{c}\text { Block } \\
\text { Cost+ } \\
\text { Speed } \\
\text { restriction } \\
\text { cost- } \\
\text { Material } \\
\text { cost }\end{array}$ & $\begin{array}{c}\text { Block } \\
\text { Cost+ } \\
\text { Speed } \\
\text { restriction } \\
\text { cost }\end{array}$ & \begin{tabular}{|c} 
Block Cost+ \\
Speed \\
restriction \\
costt \\
Material \\
cost
\end{tabular} & $\begin{array}{c}\text { Block } \\
\text { Cost+ } \\
\text { Speed } \\
\text { restrictio } \\
\text { n cost }\end{array}$ & $\begin{array}{c}\text { Block Cost+ } \\
\text { Speed } \\
\text { restriction } \\
\text { cost+ } \\
\text { Material } \\
\text { cost }\end{array}$ & $\begin{array}{c}\text { Block Cost+ } \\
\text { Speedd } \\
\text { restriction } \\
\text { cost }\end{array}$ & $\begin{array}{l}\text { Block Cost+ } \\
\text { Speced } \\
\text { restriction } \\
\text { cost+ } \\
\text { Material cost }\end{array}$ \\
\hline 1 & $\begin{array}{l}\text { RCC.T } \\
\text { Beam }\end{array}$ & 75 & 118 & 75 & 118 & 172 & 215 & 172 & 215 \\
\hline 2 & $\begin{array}{l}\text { RCC-1 } \\
\text { section }\end{array}$ & 106 & 153 & 83 & 132 & 231 & 279 & 189 & 237 \\
\hline 3 & $\begin{array}{l}\text { PSC-I } \\
\text { Section }\end{array}$ & 106 & 150 & 83 & 128 & 231 & 275 & 189 & 234 \\
\hline 4 & $\begin{array}{l}\text { Composite } \\
\text { Steel girder } \\
\text { and RCC } \\
\text { deck slab }\end{array}$ & 77 & 132 & 58 & 114 & 174 & 229 & 135 & 191 \\
\hline
\end{tabular}

The speed restrictions on the trains is a precautionary measure to avoid any miss-happening during the concreting of deck slab and generally this speed restrictions is continued till the removal of shuttering of deck slab. The cost repercussion of traffic block and speed restrictions have been calculated on account of detention of electric locomotives, coaching vehicles, goods trains, break van and payment of crew etc. In the present study, the use of sacrificial shuttering is also considered for the deck slab. The main advantage of use of sacrificial shuttering for deck slab is that, it acts as an integral part of the deck slab and left embedded permanently. With provision of sacrificial shuttering, speed restriction is not required after casting of deck slab as given in the Table IV. From Table V, the cost component of block cost and speed restriction cost not only depends on the number of trains in the section but also on type of shuttering.

\subsection{Lifecycle Cost}

The selection of the bridge superstructure will be dependent on the option consuming minimum resources during its design service life. The best methodology, to conclude the consumption of minimum resources, is one which includes all the cost spent on the superstructure during its design life and calculated on the basis of time value of money that is in terms of present value. A bridge lifecycle cost model can be expressed as follows;

$\mathrm{LCC}=\mathrm{DC}+\mathrm{CC}+\mathrm{MC}+\mathrm{RC}+\mathrm{UC}+\mathrm{SV}$

Where,

LCC = life cycle cost, DC = design cost, $C C=$ construction cost, $M C=$ maintenance cost, $R C=$ rehabilitation cost, $U C$ = user cost , and $S V=$ salvage value .

This lifecycle cost compares competing alternatives considering all significant costs. However in the present study, user cost $(\mathrm{UC}=0)$ as the construction of bridge is considered to be in green field conditions. Lifecycle cost is expressed as equivalent present worth of cost. The commonly used criterion for selecting or ranking alternative proposals is the net present value method. For calculating the net present value, following assumptions have been made:

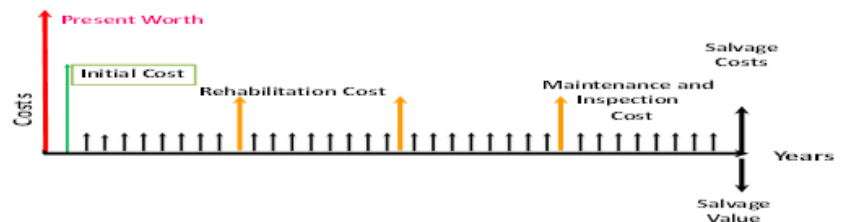

Fig. 2: Schematic diagram showing distribution of cost during service life.

i. The design life of bridge is considered to be 100 years.

ii. The maintenance cost is taken as $0.05 \%$ of the capital cost for periodic cycle of 1 year.

iii. The inspection cost is taken as $0.15 \%$ of the capital cost for periodic cycle of 2 years.

iv. The deck overlay replacement cost is taken as $10 \%$ of the capital cost for periodic cycle of 20 years.

v. The painting frequency, in case of steel bridge; is taken for periodic cycle of 8 years.

vi. The demolition cost at the end of service life of 100 years is taken as $10 \%$ of the capital cost.

vii. The salvage value in case of steel bridge is taken as $2 \%$ of the capital cost at the end of service life $o$ 100 years. 
TABLE VI

LIFECYCLE COST COMPARISON FOR VARIOUS TYPE OF SUPERSTRUCTURE FOR CONVENTIONAL AND COMBINATION OF CONVENTIONAL+ SACRIFICIAL SHUTTERING (IN LAKHS OF INR)

\begin{tabular}{|c|c|c|c|c|c|c|c|c|c|}
\hline \multirow[b]{3}{*}{ No } & \multirow[b]{3}{*}{$\begin{array}{l}\text { Super- } \\
\text { structure Type }\end{array}$} & \multicolumn{4}{|c|}{20 Trains per day } & \multicolumn{4}{|c|}{50 Trains per day } \\
\hline & & \multicolumn{2}{|c|}{$\begin{array}{l}\text { Conventional } \\
\text { Shuttering }\end{array}$} & \multicolumn{2}{|c|}{$\begin{array}{l}\text { Combination of } \\
\text { Conventional }+ \\
\text { Sacrificial } \\
\text { Shuttering }\end{array}$} & \multicolumn{2}{|c|}{$\begin{array}{l}\text { Conventional } \\
\text { Shuttering }\end{array}$} & \multicolumn{2}{|c|}{$\begin{array}{c}\text { Combination of } \\
\text { Conventional }+ \\
\text { Sacrificial Shuttering }\end{array}$} \\
\hline & & $\begin{array}{c}\text { Block } \\
\text { Cost+ } \\
\text { Speed } \\
\text { restricti } \\
\text { on cost }\end{array}$ & $\begin{array}{l}\text { Block } \\
\text { Cost+ } \\
\text { Speed } \\
\text { restricti } \\
\text { on cost+ } \\
\text { Materia } \\
\text { I cost } \\
\end{array}$ & $\begin{array}{c}\text { Block } \\
\text { Cost+ } \\
\text { Speed } \\
\text { restricti } \\
\text { on cost }\end{array}$ & $\begin{array}{c}\text { Block } \\
\text { Cost }+ \\
\text { Speed } \\
\text { restrictio } \\
\text { n cost+ } \\
\text { Material } \\
\text { cost }\end{array}$ & $\begin{array}{c}\text { Block } \\
\text { Cost+ } \\
\text { Speed } \\
\text { restrictio } \\
\text { n cost }\end{array}$ & $\begin{array}{c}\text { Block } \\
\text { Cost }+ \\
\text { Speed } \\
\text { restrictio } \\
\text { n cost }+ \\
\text { Material } \\
\text { cost }\end{array}$ & $\begin{array}{c}\text { Block } \\
\text { Cost }+ \\
\text { Speed } \\
\text { restrictio } \\
\text { n cost }\end{array}$ & $\begin{array}{c}\text { Block } \\
\text { Cost } \\
\text { Speed } \\
\text { restriction } \\
\text { cost+ } \\
\text { Material } \\
\text { cost }\end{array}$ \\
\hline 1 & RCC. T Beam & 77.08 & 120.08 & 77.08 & 120.08 & 174. & 217.08 & 174. & 217.08 \\
\hline 2 & RCC. I section & 108.28 & 155.28 & 85.28 & 134.28 & & 281.28 & & 239.28 \\
\hline 3 & PSC -I Section & 108.13 & 152.13 & 85.13 & 130.13 & 233.13 & 277.13 & 191.13 & 236.13 \\
\hline 4 & $\begin{array}{l}\text { Composite Steel } \\
\text { girder and RCC } \\
\text { deck slab }\end{array}$ & 80.91 & 135.91 & 61.91 & 117.91 & 177.91 & 232.91 & 138.91 & 194.91 \\
\hline
\end{tabular}

\section{CONCLUSION}

In the present study four types of super structures namely; reinforced concrete T-beam, reinforced concrete I- beam, prestressed concrete I-beam and steel composite I-beam are compared, from cost point of view, for $25 \mathrm{~m}$ span. The cost analysis consists of basic material cost, the effect of Railway traffic block cost as well as the cost associated with speed restriction.

i. From Table II, on the basis of material cost RCC-T Beam is most economical among all the superstructure types. However, the cost of PSC-I section is only $2.13 \%$ more than the RCC-T Beam and it is most economical option when only the superstructures with launching are compared.

ii. The effect of use of sacrificial shuttering for concreting of deck slab is also studied. Table III shows that the use of sacrificial shuttering in combination with conventional shuttering increase the cost by 3\% for RCC-I section \& PSC-I section and by $1 \%$ for Composite Steel girder and RCC deck slab. When we compare the cost after adding launching/placement cost in material/fabrication cost, RCC-T Beam remains most economical as it is constructed caste-in-situ. Among other three options, which requires launching/placement by means of hydraulic cranes; PSC-I section proves to be most economical. However, the launching/placement cost is minimum for Composite Steel girder and RCC deck slab.

iii. From Table IV, the analysis of important aspects of traffic block cost and cost associated with imposed speed restriction shows that the requirement of block duration is same for all superstructure type for both conventional as well as combination of conventional and sacrificial shuttering. However, the duration of speed restriction is reduced significantly by using sacrificial shuttering for deck slab.

iv. From Table V, when the combined effect of material cost, launching cost, traffic block cost and speed restriction cost is evaluated by considering conventional shuttering only, RCC T -Beam proves to be most economical among all types of superstructure. However, composite steel girder is best option when lunching activity using hydraulic crane is involved.

v. From Table V, when the combined effect of material cost, launching cost, traffic block cost and speed restriction cost is evaluated by considering conventional shuttering with combination of sacrificial shuttering, composite steel girder with RCC deck slab proves to be most economical among all types of superstructure.

vi. From Table V, when the combination of block cost and speed restriction cost is considered, it is lowest for Composite Steel Girder with RCC deck slab when the sacrificial shuttering is used for deck slab. In case of conventional shuttering, it is lowest for RCC-T Beam.

vii. When the Lifecycle cost is considered the as per Table VI, the lifecycle cost is lowest for Composite steel girder with RCC deck slab for both types of shuttering, where launching is involved.

\section{REFERENCES}

[1] Saxena Amit and Maru Dr. Savitri, Comparative Study of the Analysis and Design of T-Beam Girder and Box Girder Supersructure, International Journal of Research in Engineering \& Advanced Technology, April-May 2013, Vol-I, Issue 2.

[2] Heggade V.N., Mehta R.K., and Prakash R., Design and Construction of Pre-Tensioned Sutlej Bridge in Punjab, Indian Road Congress Journal, 2006, Paper No 524.

[3] Khatri Vikash, Singh P.K. and Maiti P. R., Comparative Study of Prestressed steel-concrete composite bridge of different span length and girder spacing, International Journal of Modern Engineering Research,2012, Volume 2(5), pp 3917-3922.

[4] Khatri Vikash, Singh P.K., and Maiti P. R., Comparative Study of Economical Design Aspect of Steel-Concrete Composite Bridge with MS, HPS, and Hybrid Steel, International Journal of Engineering Research and Development, 2012, Volume 4(6).

[5] M. Kishore Kumar and Rao Ch. Hanumantha, Economics of Alternative Structural Schemes of Prestressed Concrete Bridge: Few Case Studies, International Journal of Civil and Structural Engineering,2010, Volume 1(3).

[6] Standard Specifications and code of practice for road bridges, section IV- composite construction (first revision), IRC: 22-1986, The Indian Road Congress.

[7] Standard Specifications and code of practice for road bridges, IRC: 6-2000, The Indian Road Congress. 